\section{Tips on transitioning out of elite sport (judo): the athlete's perspective}

\author{
Patrick Dawson
}

\section{LOVE OF JUDO}

From the moment I started judo, I was obsessed. I started from a non-competitive sporting background at the age of 16 years old. I was extremely lucky as I walked into (what was at the time) the most successful judo club in Britain and fell in love with the sport (see figure 1). I pretty much stopped doing everything else as soon as I started doing judo!

The two best results that I had in my career were World Cup gold medals in Buenos Aires in 2013 and in February 2014 in Sofia, Bulgaria. At that time, the world number 1 that I fought was pretty much unbeaten. These were two very good days!

\section{Sport becoming the essence of you}

Any athlete who chooses to compete and train full-time makes their sport a way of life. It is the reason you get up, you eat and you sleep. There's a great moral code that goes alongside judo and in its purest form, it is a pretty good way to a holistic lifestyle.

Little else mattered, and so I didn't have the answers for how an athlete should prepare for the time that comes along when the motivation and drive by which you define yourself changes. This is specifically relevant to judo because it is an individual fighting sport. You don't get a much more brutal sport than one where you literally succeed or fail based on you physically fighting somebody-it is a war. It makes you very strong physically and mentally, but it can also be incredibly challenging and pretty lonely.

When I realised that my judo career wasn't forever, which unfortunately was after my third major injury, there was a moment of loss of identity. In the last 3 years, I did not have the success that I had previously, or wanted. I had a lot of injuries and I gradually realised that judo is not forever.

\section{The cumulative impact of injuries}

I did not think that my first and second injuries would have any effect on my sporting career. I spent as much time rehabilitating each day as I would do had I

Correspondence to Patrick Dawson, Psychology, The Open University, Walton Hall MK7 6AA, UK; patrick@rhodawn.com

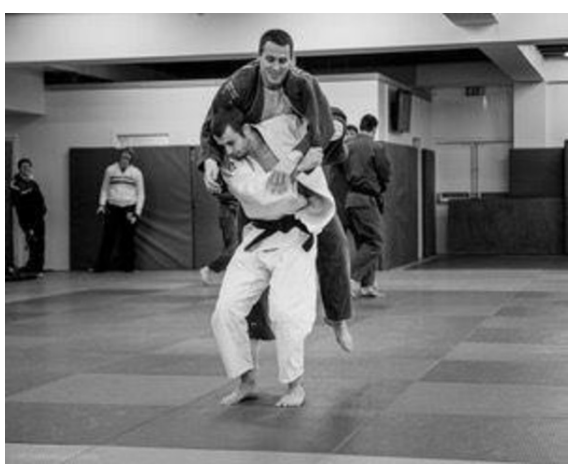

Figure 1 Technical practice with training partner, photo credits to Richard Goulding.

been doing my normal training. I rehabbed 2.5-3 hours a day for a year to return from my anterior cruciate ligament (ACL) injury. My second injury happened just as I came back, I competed for 6 months with 4 fragments of bone in my elbow, a couple the size of dental molars, and when the surgeon took them out he said he wasn't sure how I had function in my arm.

After the third time I got injured (cartilage damage to the knee in which I previously ruptured my ACL), the doctor said: 'you know, we think you can get back to competing at the level that you have, but we need to start talking about your long-term knee health'. At that point, I started thinking that I wanted to be able to play football with any kids I may have in the future, or go snowboarding, or even go for a walk.

\section{The challenge of seeking help}

There is a stigma attached to athletes showing perceived weakness or admitting that they need help. Before I was aware that I was struggling with the mental aspect of training and rehab, I didn't have the vocabulary to describe how I felt. I resisted speaking about it until I physically couldn't stop myself talking.

When I was winning, and when I was developing and progressing, it was never in question, because it was worth it. After my knee injury, nothing changed ... until everything changed, until I just had no more ability to want to get 'back on the horse'. There were a couple of days when I would turn up to judo ... and then drive home without entering the gym-and that's not me.
I pretty much haven't spoken about emotions and feelings since my childhood. I do still think that this is an issue within our sport, and within sport in general. I felt unable to talk about certain thingsand I know it's not just me. Ongoing education for athletes in mental health is very important and something that does need more focus.

\section{LIFE AFTER JUDO}

I had absolutely no plans for what would happen after my career in sport. I never doubted that I would only stop judo once I physically had to, when I couldn't fight anymore. I couldn't imagine working in anything other than judo, whether that was competing, coaching or whatever came from that. Nothing else mattered.

I think retirement (everybody hates that word) has two aspects. There's the first part of retiring - as in no longer competing in judo-and then there's what you want your working life to look like. For me that was a strange concept until recently, because I thought that I knew what my working life was going to be, judo.

This second aspect of retiring took me by surprise because as a full-time athlete in any sport, the overriding motivation is to reach the highest level possible in that field. I think that was a weakness of mine as a person but not as an athlete, that everything I had I've put into judo.

\section{Giving back to the sport}

Coaching, mentoring and helping people is what makes me happy now. I still get a lot of happiness from doing judo and I practice every single day. But when I step on the judo mat, I don't feel like I'm there to compete. I feel like I'm there to coach, and what I get the most out of is watching the younger players who look up to me. Not just for the technical issues on the mat, but with real-life issues. Hopefully, my experience can help them during their journey through sport.

\section{Three bits of advice for clinicians who} work with athletes who face emotional challenges during their sporting career

1. Be aware that the athlete might not have realised yet just how much an injury is going to affect her or him. Be prepared for the athlete to potentially have a meltdown (tears, anger, depression...).

2. Provide the athlete with the vocabulary that would enable him or her to talk about mental challenges associated with the injury. Conversations surrounding self-belief, preparation, 


\section{Patient voices}

defining success, framing failure in a wider context and differentiating between self-worth and sporting success all helped me.

3. Support the change in a sporting environment that would promote the awareness and openness about the mental pressure that the athlete is under. Things that helped me included peer-review sessions, ongoing work with a therapist, visualisation, goal setting or time/workload management and prioritisation techniques.

Contributors PD was the sole author of this piece.

Funding The author has not declared a specific grant for this research from any funding agency in the public, commercial or not-for-profit sectors.

Competing interests None declared.

Patient consent for publication Not required.

Provenance and peer review Not commissioned; internally peer reviewed.
(C) Author(s) (or their employer(s)) 2020. No commercial re-use. See rights and permissions. Published by BMJ.

\section{(A) Check for updates}

To cite Dawson P. Br J Sports Med 2020;54:755-756.

Accepted 21 July 2019

Published Online First 20 August 2019

Br J Sports Med 2020:54:755-756.

doi:10.1136/bjsports-2019-100856

ORCID iD

Patrick Dawson http://orcid.org/0000-0002-8366-4827 